\title{
Physiological and Shoot Growth Responses of Abies holophylla and Abies koreana Seedlings to Open-Field Experimental Warming and Increased Precipitation
}

\author{
Heejae Jo ${ }^{1,2} \mathbb{D}$, Florent Noulèkoun ${ }^{2} \mathbb{D}$, Asia Khamzina ${ }^{2} \mathbb{D}$, Hanna Chang ${ }^{3}$ and Yowhan Son ${ }^{1, *}$ \\ 1 Ecosystem Ecology Laboratory, Department of Environmental Science and Ecological Engineering, \\ Korea University, Seoul 02841, Korea; avianj@korea.ac.kr \\ 2 Agroforestry Systems and Ecology Laboratory (ASEL), Department of Environmental Science and Ecological \\ Engineering, Korea University, Seoul 02841, Korea; florentnoulekoun@yahoo.fr (F.N.); \\ asia_khamzina@korea.ac.kr (A.K.) \\ 3 Urban Forest Division, Forest Environment and Conservation Department, National Institute of Forest \\ Science, Seoul 02455, Korea; chn0324@korea.kr \\ * Correspondence: yson@korea.ac.kr; Tel.: +82-2-3290-3015
}

check for updates

Citation: Jo, H.; Noulèkoun, F.; Khamzina, A.; Chang, H.; Son, Y. Physiological and Shoot Growth Responses of Abies holophylla and Abies koreana Seedlings to Open-Field Experimental Warming and Increased Precipitation. Water 2022, 14, 356. https://doi.org/10.3390/ w14030356

Academic Editor:

Adriana Bruggeman

Received: 9 December 2021

Accepted: 19 January 2022

Published: 26 January 2022

Publisher's Note: MDPI stays neutral with regard to jurisdictional claims in published maps and institutional affiliations.

Copyright: (c) 2022 by the authors. Licensee MDPI, Basel, Switzerland. This article is an open access article distributed under the terms and conditions of the Creative Commons Attribution (CC BY) license (https:/ / creativecommons.org/licenses/by/ $4.0 /)$.

\begin{abstract}
Projected changes in temperature and precipitation in mid-latitude wet regions are expected to significantly affect forest ecosystems. We studied the physiological and shoot growth responses of Abies holophylla and Abies koreana seedlings to warming $\left({ }^{\circ} \mathrm{C}\right.$ above ambient temperature) and increased precipitation (irrigation with $40 \%$ of rainfall) treatments under open-field conditions. The physiological parameters, quantified by the net photosynthetic rate, transpiration rate, stomatal conductance, and total chlorophyll content, were monitored from July to October 2018. Shoot growth (i.e., root collar diameter and height) was assessed in August and December 2018. Irrespective of the treatments, the physiological parameters of both species decreased from July to August under warming treatment due to heat stress before recovering in September and October. Warming alone $(\mathrm{W})$ and warming along with increased precipitation $\left(\mathrm{W}^{*} \mathrm{P}\right)$ decreased the physiological activities of both species in July, August, and September, with more pronounced effects on A. koreana compared with $A$. holophylla. Increased precipitation resulted in the increased chlorophyll content of both species in October. Shoot growth was not generally affected by the treatments, except for a subtle reduction in height under $\mathrm{W}^{*} \mathrm{P}$ for A. koreana. A. holophylla had consistently higher values for the physiological parameters and shoot growth than A. koreana. Our results indicate that the physiological activities of the Abies species could be seriously reduced under climate change, with a more severe impact on $A$. koreana. Among the two species, A. holophylla appears to be a more robust candidate for future forest planting.
\end{abstract}

Keywords: climate change; extreme heat; gas exchange; Korean fir; needle fir; photosynthesis

\section{Introduction}

The Intergovernmental Panel on Climate Change (IPCC) has reported that global temperatures are expected to rise, particularly terrestrially [1]. However, the projected changes in precipitation will not be uniform across the globe. At the same time, there is a consensus that the mean precipitation in many mid-latitude wet regions will likely increase [1]. In Korea, which is located in the mid-latitude wet region, both temperatures and precipitation are projected to increase under climate change [1,2]. This is expected to trigger a wide range of effects on natural ecosystems, including forests $[1,3]$. The predicted net effects include declined productivity as a result of reduced tree growth, wood quality, regeneration success, and increased stress-induced tree mortality, as well as increased frequencies of forest fires, diseases, and pest outbreaks [4-8]. The impact of climate change on forests has increasingly been emphasized in the literature, because forests contain 
approximately half of the terrestrial biomass carbon stock and play an important role in the conservation of terrestrial biodiversity $[1,9,10]$. In this context, sustainable adaptive management of forests and plantations largely depends on our understanding of the phenotypic plasticity of tree species (e.g., [11]).

Heat and drought waves triggered by increased temperatures greatly impact plant carbon (C) and water relationships [12-14]. Naturally, heat stress may induce a water deficit, which exacerbates the abiotic stress for plants that have to adjust their physiological activities to water shortages, when the evaporative demand is at its largest $[7,14,15]$. In response to heat and drought stress, plants reduce stomatal conductance (gs) to limit transpirative water loss [14,16]. Apart from reduced stomatal conductance, reduced C assimilation can also occur due to the downregulation of leaf photochemistry in response to metabolic limitations at high temperatures $[17,18]$. A decreased photosynthetic rate is typically observed when the temperature exceeds the optimum range, while exposure to very high temperatures can irreversibly damage the photosynthetic system [19-21]. While chlorophyll synthesis is facilitated at high temperatures [22,23], excessive heat reportedly reduces the chlorophyll synthesis rate [24]. Growth can also be directly impaired by high temperatures if a water deficit results in low cell turgor for cell expansion [25].

The physiological and growth responses of trees to co-occurring heat and drought stresses are not yet fully understood, because plant responses vary greatly depending on the species and climatic conditions [26-32]. Previous heat stress experiments have shown that plant physiological and growth responses depend on both the temperature and water availability, suggesting the study of plant responses across levels of water deficit [14,33]. For instance, heat-induced damage to the photosynthetic apparatus in olive plants was reportedly more apparent under water deficit conditions [33]. Similarly, the productivity of Douglas fir and black locust was markedly reduced under combined heat and low water availability conditions [14]. Irrigation increases the photosynthetic rate by increasing stomatal conductance and reducing leaf temperature [34-36], thus alleviating heat and drought stress. However, excessive soil moisture and waterlogging can reduce the leaf photosynthetic rate, stomatal conductance, and chlorophyll concentration, particularly in drought-sensitive species (e.g., [37,38]). A water supply through supplemental irrigation was reported to increase the shoot growth of many tree species, particularly under arid and semi-arid climatic conditions [39-42]. In light of the variable responses of tree species, the effects of increased soil water availability on tree physiology and growth performance during periods of heat stress need to be specifically addressed.

In this study, we assessed the effects of heat, increased water availability, and the combination of these effects on two major afforestation species in Korea: Abies holophylla Maxim. and Abies koreana E. H. Wilson. These are among the dominant species in the dark coniferous forests commonly found in the Northern Hemisphere and are important for landscaping, afforestation, construction, and furniture production in Korea [43,44]. Both species are reported to have been highly affected by climate change [45-47]. The survival rate of $A$. holophylla is reduced by high temperatures, and the survival of $A$. koreana is reduced by drought stress $[29,46]$. The geographical range of both species has decreased and is projected to decline further [48]. A. koreana has been classified as an endangered species in the International Union for Conservation of Nature (IUCN) Red List of Endangered Species [49].

Using an open-field experimental system that allowed the simulation of environmental conditions similar to projected future climate change [50], we investigated the physiological and growth responses of the Abies species to warming and increased water availability during the initial plant growth stage. We focused on the early growth stages because young plants, particularly seedlings, are highly sensitive to changes in biotic and abiotic factors and are subject to high mortality [51]. Moreover, the quality and growth performance of seedlings determine the long-term survival of plant communities [52,53]. We hypothesized that (1) the physiological rate and shoot growth of A. holophylla and $A$. koreana would decrease under warming treatment due to increased heat and water stress 
but would increase under increased precipitation treatment as a result of increased soil moisture availability; (2) the physiological rate and shoot growth of both species would be higher under the combined warming and increased precipitation treatment than under the warming treatment because of the buffering effect of increased water availability; and (3) the species would differ in their physiological and growth responses, owing to their different inherent sensitivities to heat and water stress.

\section{Materials and Methods}

\subsection{Study Site}

This study was conducted at the Forest Technology and Management Research Center in Pocheon, South Korea $\left(37^{\circ} 45^{\prime} 39.1^{\prime \prime} \mathrm{N}, 127^{\circ} 10^{\prime} 15.5^{\prime \prime} \mathrm{E}\right)$, which lies in the mid-latitude temperate zone and is in a relatively wet region (Figure S1a,b). The 20-year (1998-2017) average air temperature was $10.2^{\circ} \mathrm{C}$, and the average annual precipitation was $1392.4 \mathrm{~mm}$. In the year of study (2018), the average air temperature and the annual rainfall at the study site were $10.4{ }^{\circ} \mathrm{C}$ and $1535.5 \mathrm{~mm}$, respectively [54]. During the assessment period, from April to December 2018, the air temperature reached $40.4{ }^{\circ} \mathrm{C}$ in August, which was the highest temperature ever recorded in national history [54]. The soil properties of the study site were sandy loam, with $70 \%$ sand, $10 \%$ clay, and $20 \%$ silt. The soil pH was 6.24 . The total carbon concentration, total nitrogen concentration, and carbon exchange capacity

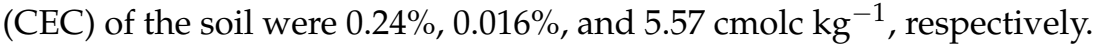

\subsection{Experimental Design}

In April 2018, A. holophylla and A. koreana seeds were sown in $1 \mathrm{~m} \times 1 \mathrm{~m}$ plots spaced $1 \mathrm{~m}$ apart (Figures S1c and S2) in an open-field experimental site. Placed at the Research Station of Forest Technology and Management Research Center in Korea, the site has been used for previous experimental climate change research, the soil of which was plowed up and replaced by nursery soil to reduce the bias of each plot. The seeds were selected according to the quality standards of forest seeds provided by the National Forest Seed and Variety Center. Following the guidelines for seed and seedling management of Korea [55], $420.3 \mathrm{~g}$ and $105.3 \mathrm{~g}$ of seeds were sown in each A. holophylla and A. koreana plot, respectively. Prior to sowing, the plots were cleared of sparse vegetation, and the site was fenced. Pests and weeds were continuously controlled throughout the experiment. Three factors were tested: (1) the 2 species, (2) warming of $3{ }^{\circ} \mathrm{C}$ above the ambient temperature, and (3) precipitation increase by irrigation, amounting to $40 \%$ of the rainfall. The warming and increased precipitation treatments included control and interactions, resulting in four levels of treatment manipulations: control $(C$, with no warming or increased precipitation), warming $(\mathrm{W})$, increased precipitation $(\mathrm{P})$, and both warming and increased precipitation $\left(\mathrm{W}^{*} \mathrm{P}\right)$. The field layout comprised a total of 24 plots (i.e., 2 species $\times 2$ levels of warming $\times 2$ levels of precipitation manipulation $\times 3$ replications; Figure S2a), where the increased precipitation plots were linearly arranged along drainage channels to prevent water flow between plots (Figure S2b).

Warming and increased precipitation management were performed to simulate the increases in temperature and precipitation projected for Korea under Representative Concentration Pathways (RCP) scenario 8.5 for 2060 [56]. Accordingly, the air temperature in the warming plots was increased by $3^{\circ} \mathrm{C}$ compared with that in the control plots (i.e., ambient air temperature) using infrared heaters (FTE-1000; Mor Electric Heating Association, Ypsilanti, MI, USA). Infrared heaters were adopted because they are widely used to simulate warming in a similar way to normal solar heating of leaves and have few side effects $[50,57,58]$. The heaters were connected to data loggers (CR1000; Campbell Inc., Ypsilanti, MI, USA) and relays (SDM-CD16AC; Campbell Inc.) and were switched off when the temperature difference between the warming and control plots measured by the infrared temperature sensors (SI-111; Campbell Inc.) reached $3{ }^{\circ} \mathrm{C}$. In the increased precipitation plots, irrigation was performed in the form of simulated increased rainfall, where $40 \%$ of the rainfall was collected and supplied to the seedlings within $24 \mathrm{~h}$ after each 
rainfall event. Rainfall was collected by covering $0.4 \mathrm{~m}^{2}$ ( $40 \%$ of the plot size) of separate rainfall harvesting plots, which were located next to the increased precipitation plots. The collected water was stored in water tanks (Figure S2b) and supplied at 9:00 a.m. every morning using pumps, timers, and button drippers. The application of both treatments was performed from the time the seeds were sown in April 2018. The warming treatment was continued until the end of the experiment in December 2018, while increased precipitation treatment was terminated in November because the environmental temperature had decreased to below the freezing point of water. Calculated from the daily precipitation of the research site, the total additional precipitation from April to November was estimated to be $559.4 \mathrm{~mm}$.

\subsection{Data Collection}

\subsubsection{Environmental Data}

Throughout the experiment, data on the air temperature $\left({ }^{\circ} \mathrm{C}\right)$, soil temperature $\left({ }^{\circ} \mathrm{C}\right)$, and soil volumetric water content $\left(\mathrm{SWC}, \mathrm{m}^{3} \mathrm{~m}^{-3}\right)$ were collected for each plot. The air temperature was measured using an infrared temperature sensor (SI-111; Campbell Inc.). The soil temperature and SWC were measured at a depth of $5 \mathrm{~cm}$ using soil temperature and moisture sensors (CS655; Campbell Inc.).

\subsubsection{Physiological and Shoot Growth Data}

Physiological and shoot growth data were measured from July to December 2018 (i.e., from the middle to the end of the growing season). Since the average days of germination were 42 and 62 days for A. holophylla and A. koreana, respectively, the data collection started at 3 months after sowing, when the shoots became sufficiently large for the measurements. Measurement of the tree physiological parameters was carried out every month from July to October 2018. These measurements were not feasible in A. koreana after October 2018 because of the high mortality rate $(>90 \%)$ of the seedlings. Three seedlings randomly selected from the middle of each plot were measured using a portable photosynthesis system (LI-6800, LI-COR Inc., USA) to determine the net photosynthetic rate $\left(\mathrm{A}, \mu \mathrm{mol} \mathrm{m} \mathrm{m}^{-2} \mathrm{~s}^{-1}\right)$, transpiration rate $\left(\mathrm{E}, \mathrm{mol} \mathrm{m} \mathrm{m}^{-2} \mathrm{~s}^{-1}\right)$, stomatal conductance $\left(\mathrm{gs}, \mathrm{mol} \mathrm{m}^{-2} \mathrm{~s}^{-1}\right)$, intracellular $\mathrm{CO}_{2}$ concentration $\left(\mathrm{Ci}, \mu \mathrm{mol} \mathrm{mol}{ }^{-1}\right)$, and ambient $\mathrm{CO}_{2}$ concentration $(\mathrm{Ca}, \mu \mathrm{mol}$ $\mathrm{mol}^{-1}$ ). The measurements were performed at ambient temperature, $400 \mathrm{ppm} \mathrm{CO}_{2}$, and $1100-1200 \mu \mathrm{mol} \mathrm{m}^{-2} \mathrm{~s}^{-1}$ artificial, photosynthetically active radiation from 8:30 a.m. to 11:30 a.m. Each physiological property was expressed per unit needle leaf area by dividing its value by the area of the needle, measured using a scanner (Perfection V700, Epson, Japan). After the measurement of gas exchange, each needle was cut into 2-mm pieces, and $0.2( \pm 0.01) \mathrm{g}$ of fragmented needles were incubated in $5 \mathrm{~mL}$ of dimethyl sulfoxide (DMSO) for 6 hours at $65^{\circ} \mathrm{C}$ to extract chlorophyll [59]. The total chlorophyll content of each needle was then calculated by measuring the absorbance of the solution at $665 \mathrm{~nm}$ and $648 \mathrm{~nm}$ using a spectrophotometer (U-1100, Hitachi, Japan).

The plant growth parameters were measured twice: in August and December 2018. In August, 30 seedlings were selected from the middle of each plot, tagged, and measured for their height and root collar diameter (RCD). The tagged seedlings were measured again in December, excluding defoliated and dead seedlings.

\subsection{Statistical Analyses}

A linear model was used to analyze differences in the physiological and growth variables with respect to species, warming, increased precipitation, and their interactions. ANOVA was performed on the linear model to assess the overall significance of the main and interaction effects. Because the initial results showed a significant effect of time for all the physiological and growth variables (Table 1), a separate model was used for each of the months of assessment (Table S1). The statistical analyses consisted of two steps. First, the main effects of the species, warming, and increased precipitation on the physiological and growth variables were tested. Second, the differences between the species were analyzed 
with respect to the four levels of treatment (i.e., $\mathrm{C}, \mathrm{W}, \mathrm{P}$, and $\mathrm{W}^{*} \mathrm{P}$ ). Prior to the analyses, each variable was checked for normal distribution using the Shapiro-Wilk test. When the assumption of normality was not met, the variable was either square root- or logtransformed. The Tukey multiple comparison test was performed for mean comparisons when a significant treatment effect was identified. Unless stated otherwise, the mean values were calculated from the original data. Moreover, due to large variations in the initial physiological and growth data and the lack of observations for some of the treatments (e.g., $\mathrm{W}^{*} \mathrm{P}$ treatment for $A$. koreana), the $95 \%$ confidence interval (CI) of the mean was also plotted to support the results of the Tukey multiple comparison test. Non-overlapping $95 \% \mathrm{CIs}$ indicated significant differences between treatments at $<5 \%$. All statistical analyses were performed using R statistical software version 4.0.0 (R Core Team, 2020).

Table 1. Results ( $p$-values) of the initial ANOVA testing for the main and interaction effects of all experimental factors on the physiological (A, E, gs, Chl, and $\mathrm{Ci} / \mathrm{Ca}$ ) and growth (height and $\mathrm{RCD}$ ) parameters of Abies holophylla and Abies koreana seedlings.

\begin{tabular}{|c|c|c|c|c|c|c|c|}
\hline \multirow[t]{2}{*}{ Parameters } & \multicolumn{5}{|c|}{ Physiology } & \multicolumn{2}{|c|}{ Growth } \\
\hline & A & $\mathbf{E}$ & $g_{s}$ & Chl & $\mathrm{Ci} / \mathrm{Ca}$ & Height & RCD \\
\hline $\mathrm{Sp}$ & 0.080 & 0.071 & $<0.001$ & 0.024 & 0.053 & $<0.001$ & $<0.001$ \\
\hline $\mathbf{W}$ & $<0.001$ & $<0.001$ & $<0.001$ & 0.013 & 0.007 & 0.647 & 0.157 \\
\hline $\mathbf{P}$ & 0.205 & 0.228 & 0.294 & 0.106 & 0.023 & 0.254 & 0.89 \\
\hline Time & $<0.001$ & $<0.001$ & $<0.001$ & $<0.001$ & $<0.001$ & $<0.001$ & $<0.001$ \\
\hline $\mathrm{Sp}^{* W}$ & 0.649 & 0.016 & 0.111 & 0.843 & 0.378 & 0.026 & 0.062 \\
\hline $\mathrm{Sp}^{*} \mathbf{P}$ & 0.331 & 0.77 & 0.841 & 0.543 & 0.025 & 0.529 & 0.824 \\
\hline $\mathbf{W}^{*} \mathbf{P}$ & 0.423 & 0.7 & 0.84 & 0.027 & 0.393 & 0.501 & 0.353 \\
\hline Time*Sp & 0.134 & 0.003 & 0.215 & $<0.001$ & $<0.001$ & 0.502 & 0.388 \\
\hline Time $^{*} \mathbf{W}$ & 0.003 & $<0.001$ & $<0.001$ & 0.422 & $<0.001$ & 0.473 & 0.654 \\
\hline Time$^{*} \mathrm{P}$ & 0.721 & 0.728 & 0.845 & 0.327 & 0.621 & 0.432 & 0.596 \\
\hline$S p^{*} W^{*} \mathrm{P}$ & 0.363 & 0.1 & 0.205 & 0.494 & 0.426 & 0.356 & 0.386 \\
\hline Time $^{*} \mathrm{Sp}^{* W}$ & 0.818 & 0.677 & 0.733 & 0.773 & 0.148 & 0.803 & 0.36 \\
\hline Time $^{*} \mathrm{Sp}^{* \mathrm{P}}$ & 0.544 & 0.626 & 0.706 & 0.988 & 0.819 & 0.054 & 0.569 \\
\hline Time $^{*} \mathrm{~W}^{*} \mathrm{P}$ & 0.438 & 0.729 & 0.457 & 0.636 & 0.704 & 0.574 & 0.833 \\
\hline Time $^{*} \mathrm{Sp}^{*} \mathrm{~W}^{*} \mathrm{P}$ & 0.743 & 0.954 & 0.912 & 0.855 & 0.290 & 0.711 & 0.676 \\
\hline
\end{tabular}

Sp: species; W: warming; P: increased precipitation; Time: month of assessment; A: net photosynthetic rate; E: transpiration rate; gs: stomatal conductance; Chl: total chlorophyll content; $\mathrm{Ci}$ : intercellular $\mathrm{CO}_{2}$ concentration; Ca: ambient $\mathrm{CO}_{2}$ concentration; RCD: root collar diameter. Significant $p$-values are highlighted in bold.

\section{Results}

\subsection{Environmental Conditions}

The daily average air and soil temperatures increased steadily from April to a peak in August before decreasing over the rest of the year in all plots (Figure 1). The lowest values of the daily averaged SWC were recorded in April and August, whereas the peak values corresponded with rainfall and irrigation events. Higher air and soil temperatures were recorded under $W$ and $W^{*} P$ treatments compared with $C$ (Figure 1a,b,d,e), with the air temperature in the $\mathrm{W}^{*} \mathrm{P}$ plots averaging $+2.8-3.3{ }^{\circ} \mathrm{C}$ above the ambient conditions (Table S2). Conversely, the SWC was higher under P with an average amount of 9.0-25.8\% compared with C (Table S2 and Figure 1c,f). Furthermore, species differences were observed. For instance, the soil temperature under the two warming treatments (i.e., $\mathrm{W}$ and $\mathrm{W}^{*} \mathrm{P}$ ) was higher in the A. koreana plots than in the A. holophylla plots (Figure 1e). For A. koreana, the SWC was consistently the lowest under $\mathrm{W}$, while the range of the SWC in the $\mathrm{P}$ and $\mathrm{W}^{*} \mathrm{P}$ plots was similar to that in the $C$ plots (Figure 1f). In contrast, the range of the SWC values in $\mathrm{W}$ and $\mathrm{W}^{*} \mathrm{P}$ was similar to that in $\mathrm{C}$ for $A$. holophylla and was consistently the highest under $\mathrm{P}$ (Figure 1c). These overall patterns were also evident in the monthly means for the environmental parameters presented in Figure S3. 
Abies holophylla

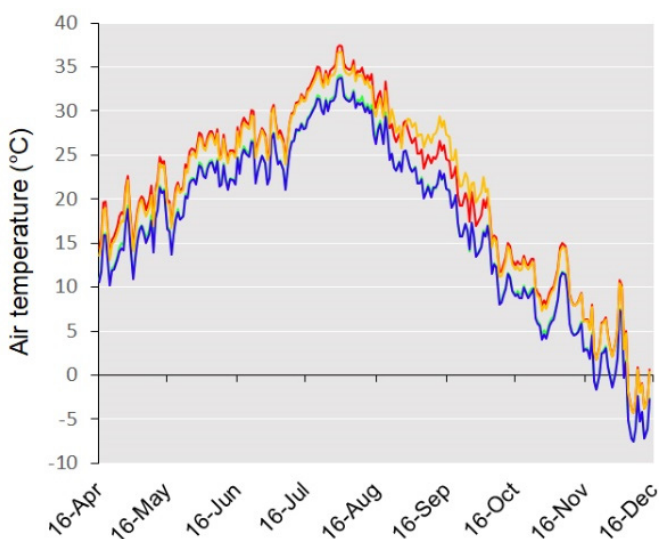

(a)

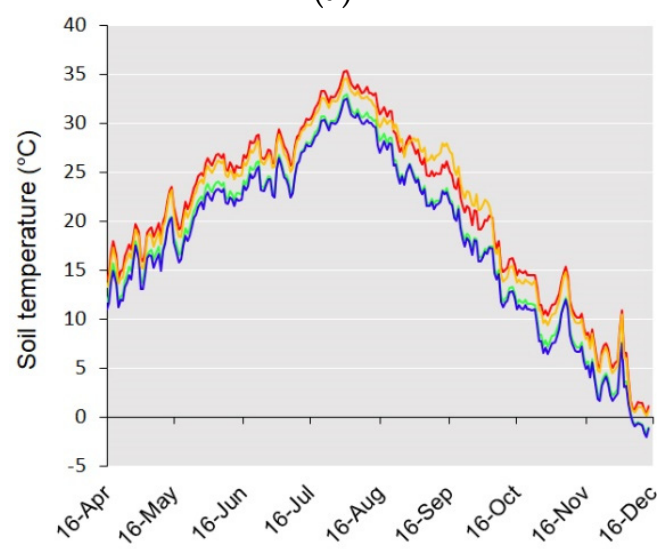

(b)

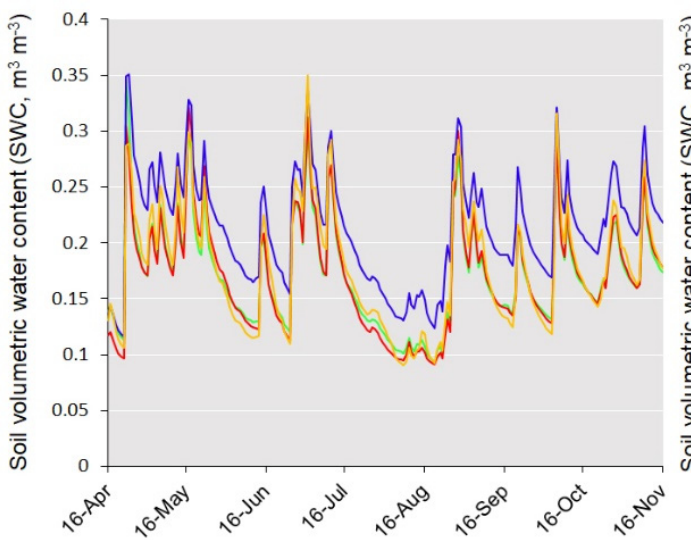

(c)
Abies koreana

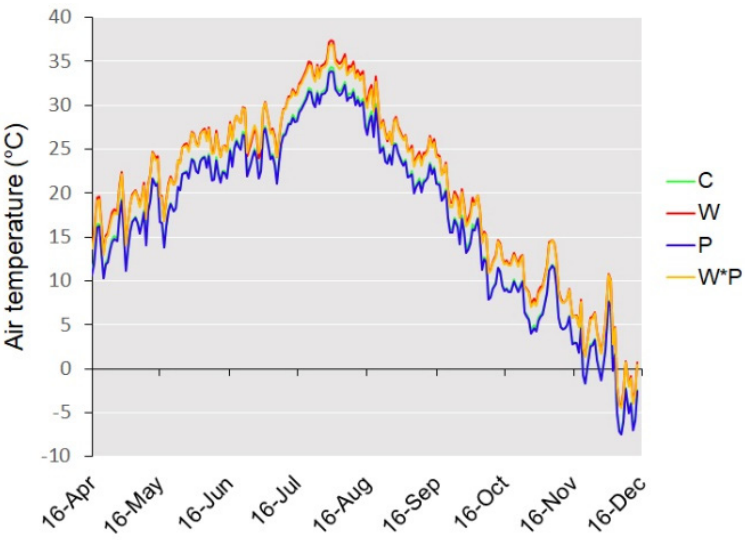

(d)

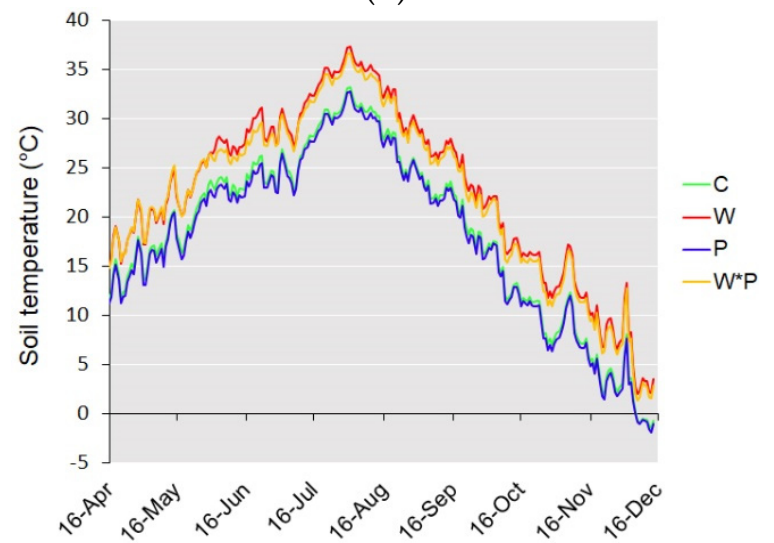

(e)

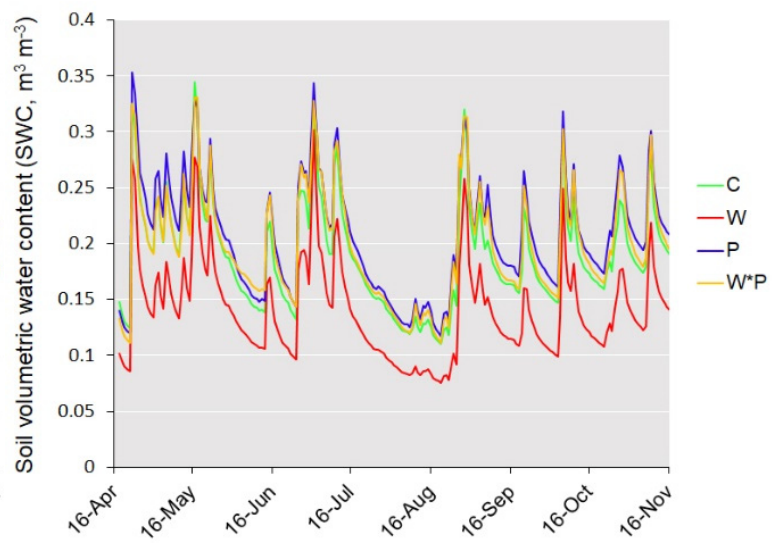

(f)

Figure 1. (a,d) Air temperature, (b,e) soil temperature, and (c,f) soil volumetric water content (SWC) under the four treatments over the entire experimental period. Shown are the daily averaged values for Abies holophylla and Abies koreana. Air and soil temperatures were measured from April to December. SWC was measured from April to November. The treatments included control (C), warming $(\mathrm{W})$, increased precipitation $(\mathrm{P})$ and both warming and increased precipitation $\left(\mathrm{W}^{*} \mathrm{P}\right)$. Averaged monthly data are presented in Figure S3.

\subsection{Physiological Responses to Warming and Increased Precipitation Treatments}

The two species differed significantly in all physiological responses during the assessment periods (Tables 1,2 and S1). Overall, A. holophylla consistently had higher values for A, E, gs, Chl, and Ci/Ca than A. koreana. Significant differences between the two species 
occurred in August, September, and October, with more pronounced effects in August. In particular, A. koreana showed a negative A in August $\left(-0.131 \mu \mathrm{mol} / \mathrm{m}^{-2} \mathrm{~s}^{-1}\right)$, suggesting that the rate of respiration exceeded the photosynthetic rate for this species in August (Table 2).

Table 2. Effect of tree species, warming $(\mathrm{W})$, and increased precipitation $(\mathrm{P})$ on the physiological (A, $\mathrm{E}, \mathrm{gs}, \mathrm{Chl}$, and $\mathrm{Ci} / \mathrm{Ca}$ ) and growth (height and $\mathrm{RCD}$ ) parameters of Abies holophylla and Abies koreana seedlings.

\begin{tabular}{|c|c|c|c|c|c|c|c|c|c|c|c|c|c|}
\hline & & \multicolumn{12}{|c|}{ Physiology } \\
\hline & & \multicolumn{4}{|c|}{$\mathrm{A}\left(\mu \mathrm{mol} \mathrm{m} \mathrm{m}^{-2} \mathrm{~s}^{-1}\right)$} & \multicolumn{4}{|c|}{$E\left(\mathrm{~mol} \mathrm{~m}^{-2} \mathrm{~s}^{-1}\right)$} & \multicolumn{4}{|c|}{ gs $\left(\mathrm{mol} \mathrm{m}^{-2} \mathrm{~s}^{-1}\right)$} \\
\hline & & Jul & Aug & Sep & Oct & Jul & Aug & Sep & Oct & Jul & Aug & Sep & Oct \\
\hline \multirow{2}{*}{ Sp } & $\mathrm{Ah}$ & $6.61^{\mathrm{a}}$ & $0.95^{\mathrm{a}}$ & $5.17^{\mathrm{a}}$ & $5.55^{\mathrm{a}}$ & $0.13^{a}$ & $0.05^{\mathrm{a}}$ & $0.14^{\mathrm{a}}$ & $0.07^{a}$ & $0.07^{a}$ & $0.02^{a}$ & $0.07^{\mathrm{a}}$ & $0.08^{a}$ \\
\hline & $\mathrm{Ak}$ & $6.24^{\mathrm{a}}$ & $-0.13^{b}$ & $5.02^{\mathrm{a}}$ & $6.13^{a}$ & $0.14^{\mathrm{a}}$ & $0.02^{b}$ & $0.11^{\mathrm{a}}$ & $0.06^{\mathrm{a}}$ & $0.06^{a}$ & $0.01^{b}$ & $0.06^{\mathrm{a}}$ & $0.06^{b}$ \\
\hline \multirow{2}{*}{ W } & No W & $7.09^{a}$ & $0.97^{\mathrm{a}}$ & $6.11^{\mathrm{a}}$ & $5.99^{a}$ & $0.14^{\mathrm{a}}$ & $0.04^{\mathrm{a}}$ & $0.15^{a}$ & $0.07^{a}$ & $0.07^{a}$ & $0.02^{a}$ & $0.08^{a}$ & $0.08^{a}$ \\
\hline & W & $5.75^{b}$ & $-0.16^{b}$ & $3.61^{b}$ & $5.38^{a}$ & $0.12^{b}$ & $0.03^{b}$ & $0.09^{b}$ & $0.06^{\mathrm{a}}$ & $0.06^{\mathrm{a}}$ & $0.01^{\mathrm{a}}$ & $0.05^{b}$ & $0.07^{\mathrm{a}}$ \\
\hline \multirow{5}{*}{$\mathrm{P}$} & No P & $6.10^{a}$ & $0.35^{\mathrm{a}}$ & $5.08^{a}$ & $5.66^{\mathrm{a}}$ & $0.13^{a}$ & $0.03^{a}$ & $0.13^{a}$ & $0.07^{a}$ & $0.06^{a}$ & $0.01^{\mathrm{a}}$ & $0.07^{\mathrm{a}}$ & $0.07^{a}$ \\
\hline & $\mathrm{P}$ & $6.74^{\mathrm{a}}$ & $0.57^{\mathrm{a}}$ & $5.13^{\mathrm{a}}$ & $5.88^{a}$ & $0.13^{a}$ & $0.04^{\mathrm{a}}$ & $0.13^{a}$ & $0.07^{a}$ & $0.07^{\mathrm{a}}$ & $0.02^{\mathrm{a}}$ & $0.07^{\mathrm{a}}$ & $0.07^{\mathrm{a}}$ \\
\hline & & \multicolumn{8}{|c|}{ Physiology } & \multicolumn{4}{|c|}{ Growth } \\
\hline & & \multicolumn{4}{|c|}{ Chl $\left(\mathrm{mg} \mathrm{g}^{-1}\right)$} & \multicolumn{4}{|c|}{$\mathrm{Ci} / \mathrm{Ca}$} & \multicolumn{2}{|c|}{ Height (cm) } & \multicolumn{2}{|c|}{$\mathrm{RCD}(\mathrm{mm})$} \\
\hline & & Jul & Aug & Sep & Oct & Jul & Aug & Sep & Oct & Aug & Dec & Aug & Dec \\
\hline \multirow{2}{*}{ Sp } & $\mathrm{Ah}$ & $0.18^{a}$ & $0.14^{\mathrm{a}}$ & $0.15^{\mathrm{a}}$ & $0.15^{\mathrm{a}}$ & $0.59^{a}$ & $0.80^{\mathrm{a}}$ & $0.68^{a}$ & $0.69^{a}$ & $2.87^{\mathrm{a}}$ & $3.55^{\mathrm{a}}$ & $0.97^{\mathrm{a}}$ & $1.44^{\mathrm{a}}$ \\
\hline & Ak & $0.20^{\mathrm{a}}$ & $0.10^{b}$ & $0.12^{b}$ & $0.13^{a}$ & $0.56^{\mathrm{a}}$ & $0.98^{a}$ & $0.59^{b}$ & $0.59^{b}$ & $1.36^{b}$ & $1.96^{\mathrm{b}}$ & $0.47^{b}$ & $0.99^{b}$ \\
\hline \multirow{2}{*}{ W } & No W & $0.20^{\mathrm{a}}$ & $0.14^{\mathrm{a}}$ & $0.15^{\mathrm{a}}$ & $0.14^{\mathrm{a}}$ & $0.57^{\mathrm{a}}$ & $0.75^{b}$ & $0.65^{a}$ & $0.65^{a}$ & $2.07^{a}$ & $2.75^{a}$ & $0.73^{a}$ & $1.23^{\mathrm{a}}$ \\
\hline & W & $0.18^{a}$ & $0.11^{\mathrm{a}}$ & $0.13^{a}$ & $0.15^{\mathrm{a}}$ & $0.58^{a}$ & $1.04^{\mathrm{a}}$ & $0.64^{a}$ & $0.68^{a}$ & $2.31^{\mathrm{a}}$ & $3.03^{a}$ & $0.76^{\mathrm{a}}$ & $1.26^{\mathrm{a}}$ \\
\hline \multirow{2}{*}{$\mathrm{P}$} & No P & $0.19^{a}$ & $0.12^{a}$ & $0.14^{\mathrm{a}}$ & $0.13^{b}$ & $0.58^{a}$ & $0.93^{a}$ & $0.66^{a}$ & $0.67^{a}$ & $2.25^{a}$ & $2.83^{a}$ & $0.73^{a}$ & $1.24^{\mathrm{a}}$ \\
\hline & $\mathrm{P}$ & $0.19^{a}$ & $0.13^{a}$ & $0.14^{\mathrm{a}}$ & $0.16^{\mathrm{a}}$ & $0.56^{\mathrm{a}}$ & $0.81^{\mathrm{a}}$ & $0.63^{a}$ & $0.65^{a}$ & $2.12^{a}$ & $2.92^{\mathrm{a}}$ & $0.76^{\mathrm{a}}$ & $1.26^{\mathrm{a}}$ \\
\hline
\end{tabular}

Mean values are presented. Sp: species; W: warming; P: increased precipitation; Ah: Abies holophylla; Ak: Abies koreana; A: net photosynthetic rate; E: transpiration rate; gs: stomatal conductance; Chl: total chlorophyll content; Ci: intercellular $\mathrm{CO}_{2}$ concentration; $\mathrm{Ca}$ : ambient $\mathrm{CO}_{2}$ concentration; $\mathrm{RCD}$ : root collar diameter. For each attribute and month of assessment, the means with the same superscript within the same column are not significantly different at $p<0.05$ between the species, warming, and increased precipitation treatments.

Across the species, warming treatment significantly reduced A, E, and gs, mostly in July, August, and September (Table 2). However, Ci/Ca increased under W in August. Unlike W, P had a minor influence on the physiological parameters, with only a significant positive effect (i.e., increase) on $\mathrm{Chl}$ in October. Across the assessment periods, the overall patterns of the physiological responses to treatments were similar for both species, as evidenced by the lack of third- and fourth-level interactions (Table 1 and Figure 2). Except for $\mathrm{Chl}$ and $\mathrm{Ci} / \mathrm{Ca}, \mathrm{A}, \mathrm{E}$, and gs decreased from July to August before recovering in September. The range of values observed for A and gs in September was maintained in October, whereas E decreased further in October (Table 2 and Figure 2).

However, the species differed in their responses to the treatments within each assessment period (Table 1 and Table S1). For A. holophylla, W and $\mathrm{W}^{*} \mathrm{P}$ significantly reduced A in July and August and A, E, gs, and Chl in September. Ci/Ca was significantly higher under $\mathrm{W}$ and $\mathrm{W}^{*} \mathrm{P}$ in August (Figure 2e). In October, there was no significant effect from $\mathrm{W}$ on the physiological parameters, but $\mathrm{P}$ significantly increased A and Chl compared with $\mathrm{C}$ (Figure 2a,d). For $A$. koreana, large variations were observed in the physiological responses to the treatments. Nonetheless, $W$ significantly reduced $E$ in July, $W^{*} P$ reduced Chl in August, and both $W$ and $W^{*} P$ reduced A, E, and gs in September (Figure 2f-i). Consequently, in October, the mortality rate of the $A$. koreana seedlings under $\mathrm{W}$ and $\mathrm{W}^{*} \mathrm{P}$ treatments was $91.7 \%$. 


\subsection{Growth Responses to Warming and Increased Precipitation Treatments}

A. holophylla had consistently higher values for height and RCD than A. koreana on either measurement date (Tables 1 and 2). Both the height and RCD increased from August to December, with a more pronounced increase in the RCD (Figure 3). There were no significant main effects from the treatment on the height or RCD (Tables 1 and 2). However, a subtle difference was observed between species with regard to their height response to treatments in August (Tables 1 and S1). For instance, $\mathrm{W}^{*} \mathrm{P}$ significantly reduced the height of $A$. koreana only in August (Figure 3c).

Abies holophylla

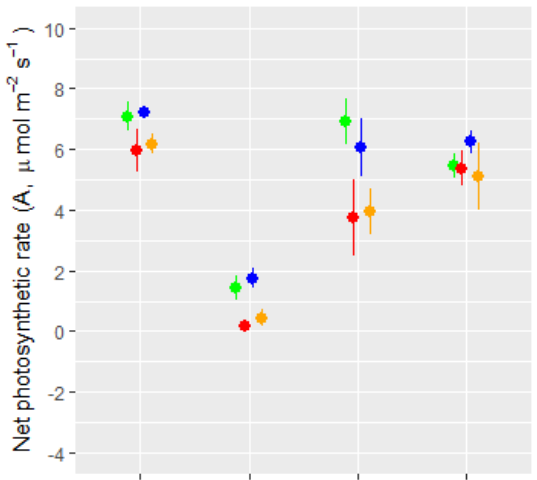

(a)

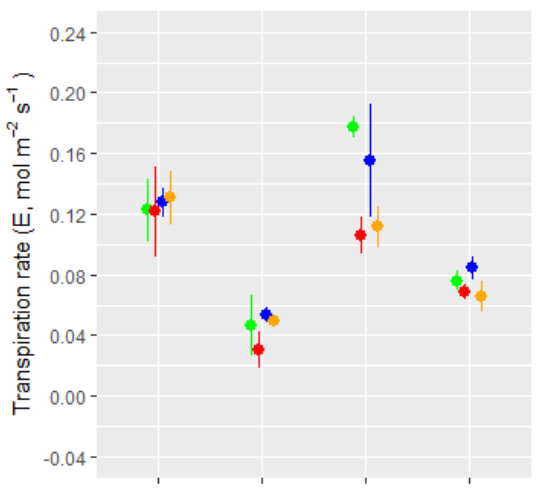

(b)

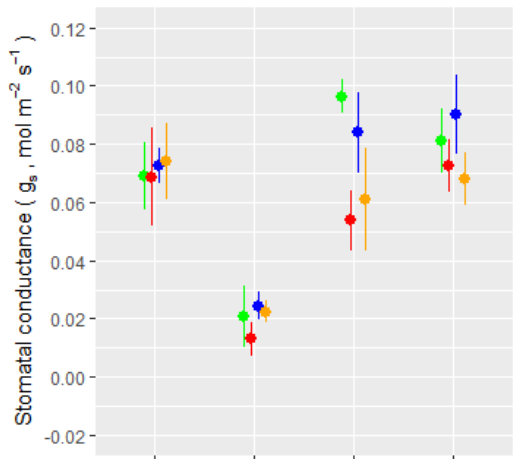

(c)
Abies koreana

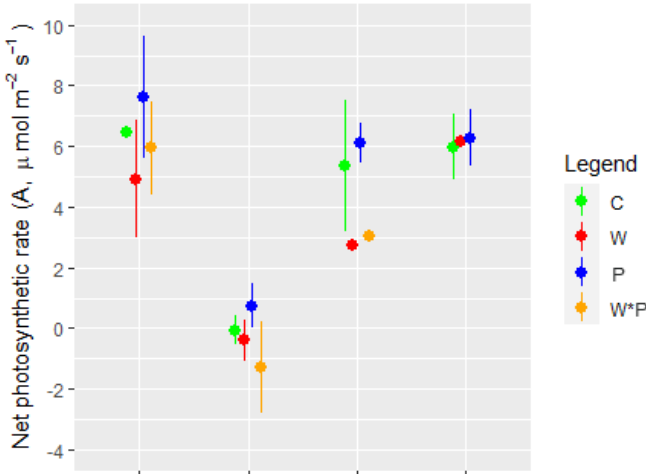

(f)

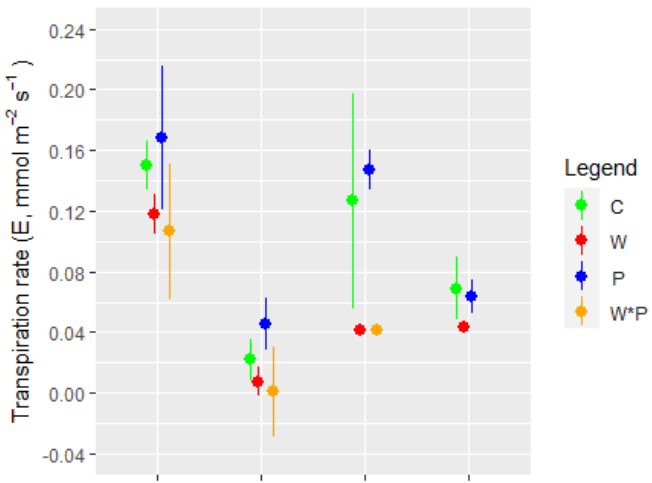

(g)

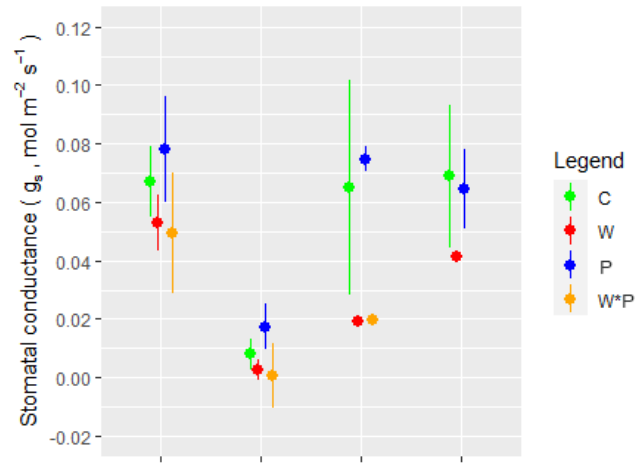

(h)

Figure 2. Cont. 


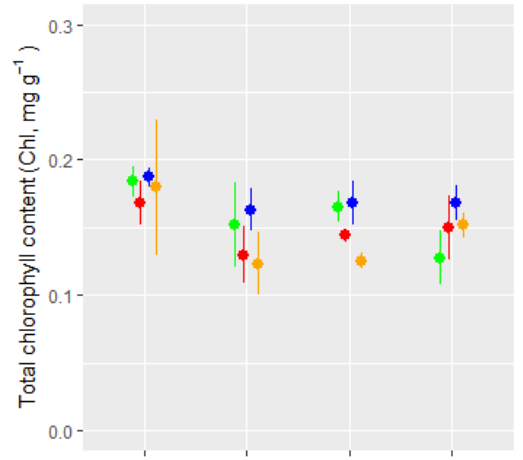

(d)

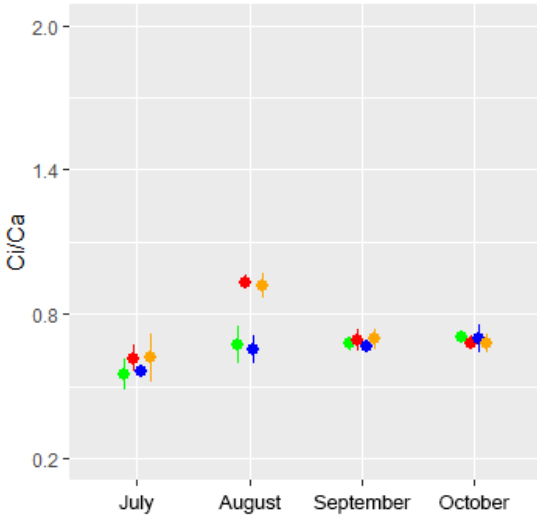

(e)

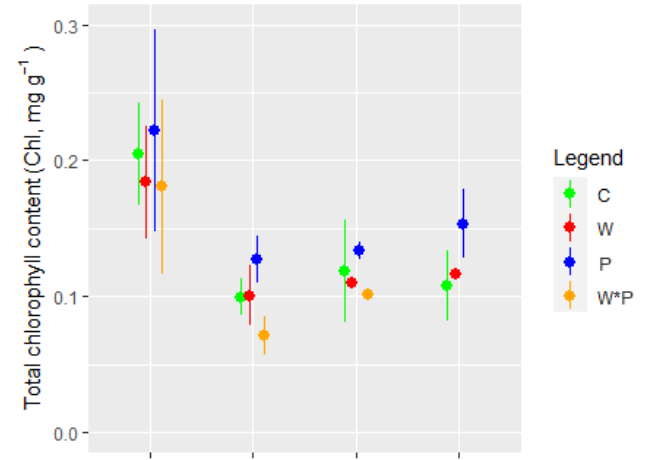

(i)

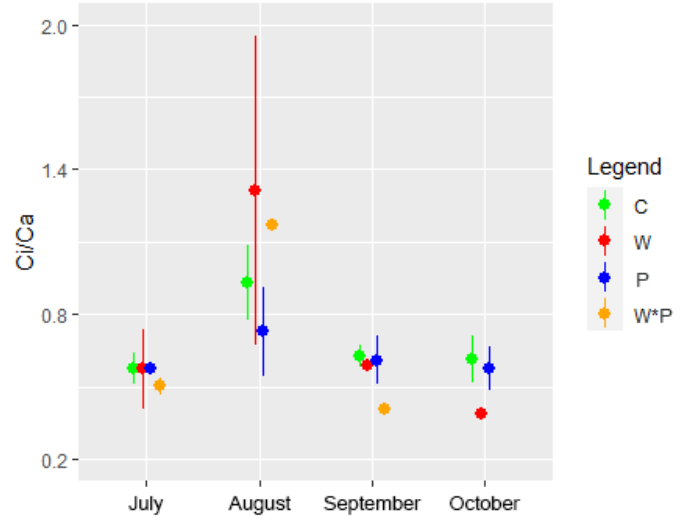

(j)

Figure 2. Effects of treatments on the physiological parameters of $(\mathbf{a}-\mathbf{e})$ Abies holophylla and $(\mathbf{f}-\mathbf{j})$ Abies koreana. The dots are the mean values, and the bars represent the $95 \%$ confidence intervals (CIs). The measurements were conducted within 1 day from 8:30 a.m. to 11:30 a.m. The treatments included control $(\mathrm{C})$, warming $(\mathrm{W})$, increased precipitation $(\mathrm{P})$, and both warming and increased precipitation $\left(\mathrm{W}^{*} \mathrm{P}\right)$.

Abies holophylla

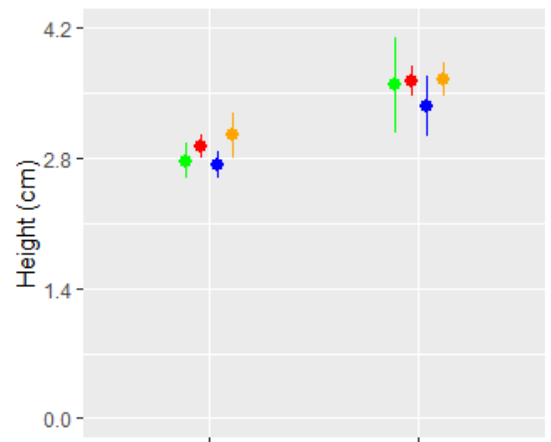

(a)

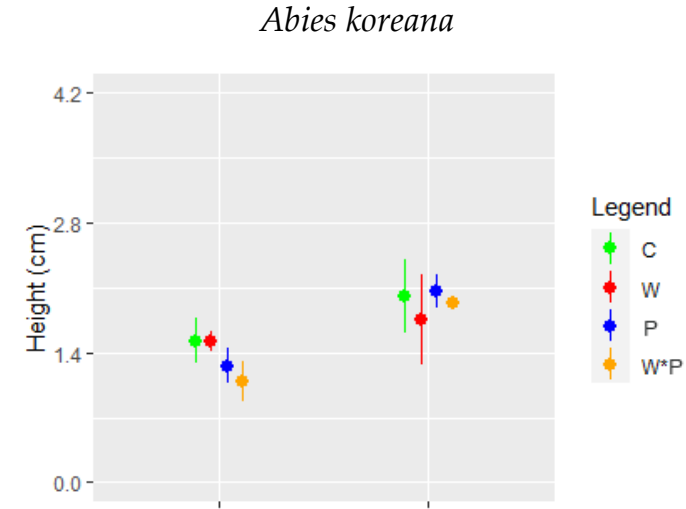

(c)

Figure 3. Cont. 


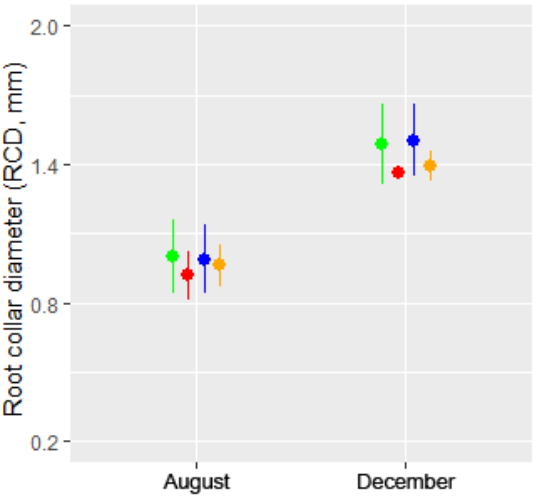

(b)

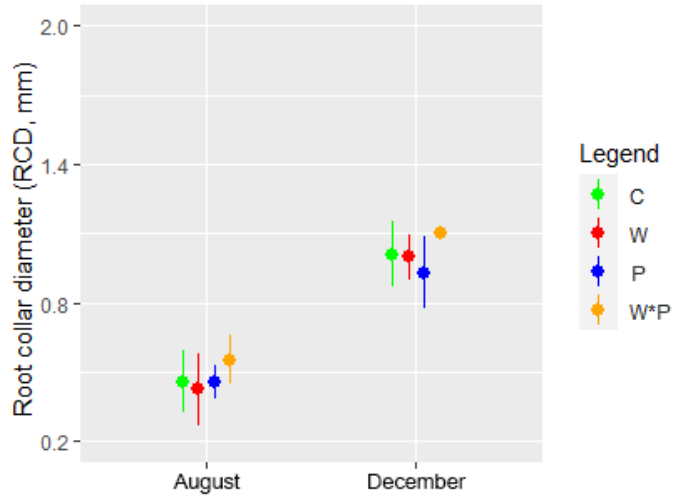

(d)

Figure 3. Effects of treatments on the shoot growth of Abies holophylla $(\mathbf{a}, \mathbf{b})$ and Abies koreana (c,d). The dots are the mean values, and the bars represent the $95 \%$ confidence intervals (CIs). The growth parameters were measured in August and December. The treatments included control $(\mathrm{C})$, warming $(\mathrm{W})$, increased precipitation $(\mathrm{P})$, and both warming and increased precipitation $\left(\mathrm{W}^{*} \mathrm{P}\right)$.

\section{Discussion}

\subsection{Effects of Warming and Increased Precipiation on Plant Physiological Parameters}

Temperature increases have been reported to negatively impact the physiological parameters of many plant species [60-65]. Accordingly, we observed a decrease in physiological activities in both species under $W$ during most of the observation period. This finding supports our first hypothesis that the physiological rate decreases under $W$ due to heat and water stress. Among the examined physiological parameters, those related to the gas exchange system, such as A, E, and gs, were highly affected. The observed decrease in A could be attributed to stomatal closure under high temperatures as a result of water stress, since both Abies species are isohydric species [16,66,67]. However, while A significantly decreased from July to September, significant reductions in E and gs occurred mainly in September, particularly in A. holophylla. This result suggests that the decrease in the photosynthetic activity of the species was not only mediated by stomatal limitations but also may have occurred due to other mechanisms. Possible factors include increased photorespiration [68] and the downregulation of leaf photochemistry (e.g., reduced activation of RuBP carboxylase-oxygenase (Rubisco)) in response to metabolic (e.g., biochemical and mesophyll) limitations under excessive heat stress, as previously observed in heat experiments on oak and pine trees $[14,18]$. The higher $\mathrm{Ci} / \mathrm{Ca}$ under $\mathrm{W}$ compared with $\mathrm{C}$ for A. holophylla in August further supports the evidence that the $\mathrm{CO}_{2}$ limitation caused by stomatal closure did not significantly affect A (Figure S4). The lack of stomatal closure to the increased temperature in July and August may be explained by the availability of sufficient water under the $\mathrm{W}$ treatment (as shown by the lack of significant differences in SWC between C (July average of $17.99 \%$ and August average of $13.04 \%$ ) and W (July average of $17.88 \%$ and August average of $12.69 \%$ ) for A. holophylla) or the evaporative cooling process $[14,18,69]$. However, the fact that stomatal limitations and the reduction in Chl under W became more apparent in September despite the similar levels of SWC under $\mathrm{C}$ and $\mathrm{W}$ for the species likely reflects the overwhelming heat stress that the plants experienced in the previous month. In contrast, stomatal limitations induced by water stress appear to have contributed to the decrease in the photosynthetic activity of $A$. koreana seedlings, as evidenced by the significant reductions in E in July and September as well as in the SWC under the W treatment.

If heat-induced water stress decreased the photosynthetic activity of the species, we would expect an additional water supply to buffer the negative effects of $W$ on the physiological rates of the species (i.e., our second hypothesis) via evaporative cooling and increased soil water availability for root uptake. However, we found that $\mathrm{W}^{*} \mathrm{P}$ did not alleviate the negative effect of heat stress on the physiological parameters of the plants 
when compared with the $\mathrm{W}$ treatment. Although the physiological performance decrement of $A$. koreana was reported at SWC $<5 \%$, the species recovered after re-watering [70]. The lack of an increased precipitation effect on the physiological parameters of the species in July, August, and September suggests that despite the increased soil moisture availability, the water supplied to the seedlings did not increase stomatal conductance and thus the photosynthetic rate or mitigate the heat stress. Considering that the minimum average daily SWC was $7.57 \%$ even in the warming plots, $A$. holophylla and $A$. koreana may not have experienced significant water stress to reduce their physiological rates in this study. The positive effect of increased water availability as manifested by increased Chl production was only observed by the end of the growing season in October, when the air and soil temperatures were lower and heat stress was reduced.

Irrespective of the treatments, both species recovered their photosynthetic activity following the extreme heat stress endured during August. This result is in agreement with the findings of other studies that reported the recovery of photosynthesis in minutes to weeks after heat stress (e.g., $[18,71])$. However, the heat-induced damage to the photosynthetic apparatus was irreversible under $\mathrm{W}$ treatment, resulting in the death of several A. koreana seedlings in September and October. In a greenhouse experiment involving Abies alba Mill., irrecoverable injuries to the photosynthetic system were also recorded at approximately $47^{\circ} \mathrm{C}$ [72]. These findings also support the hypothesis that photosynthesis recovery following heat stress is species-dependent [18]. Moreover, the lack of significant differences between the $\mathrm{W}$ and $\mathrm{C}$ treatments in October likely reflects a post-stress compensation of photosynthetic activity in the seedlings subjected to the $\mathrm{W}$ treatment under more bearable conditions in October $[14,20,73,74]$.

\subsection{Effects of Warming and Increased Precipiation on Shoot Growth of the Species}

Previous studies on the growth responses of the genus Abies to variations in temperature and precipitation have reported variable results. These include an increase in RCD for $A$. holophylla seedlings and the inconsistent response of $A$. koreana seedlings under warming [29], an increase in radial growth for adult $A$. koreana under higher daily temperatures and a day-to-day radial increment increase under a greater amount of daily precipitation [75], an increase and decrease in annual ring width for adult $A$. alba under warming in temperate and drought-prone regions, respectively [76], and an increase and decrease in annual ring width for adult $A$. koreana under increased precipitation or high fall temperatures and high winter temperatures, respectively [46]. In the present study, the overall growth rates of both species in August were lower than the results found in a previous study performed at the same site [29], which might have been the result of excessive summer temperatures in 2018 [54]. However, in this study, among all treatments, only the $\mathrm{W}^{*} \mathrm{P}$ effect on shoot growth was significant, manifested through the reduced height growth of $A$. koreana. This response is expected given the reduced A under $\mathrm{W}^{*} \mathrm{P}$ in August and because carbon assimilation is closely linked to plant growth [77]. The general lack of shoot growth responses to the treatments was unexpected, given that warming significantly decreased A between July and September. However, the root responses to the treatments were not examined. Overall, our findings suggest that physiological responses to warming and water availability are more immediate, whereas aboveground growth responses are less obvious to discern as they occur gradually [78].

\subsection{Plant Adaptation to Climate Change}

The success of the early growth stages is crucial because it affects the dynamics and persistence of plant communities [79]. Therefore, understanding the potential ability of seedlings to respond and adapt to projected environmental stresses (e.g., [41,42]) under climate change is necessary for the success of future afforestation efforts. Based on their response to warming treatment, $A$. koreana seedlings appeared more vulnerable to heat stress and water deficits than $A$. holophylla, as evidenced by their negative photosynthetic rate under extreme heat waves in August, reduced height growth, and high mortality. The 
performance of the $A$. holophylla seedlings was more robust under microclimate manipulation. Conversely, Han et al. [29] reported a generally higher A for A. koreana than for $A$. holophylla but made these observations under lower air temperature conditions $\left(1.8^{\circ} \mathrm{C}\right.$ and $1.3^{\circ} \mathrm{C}$ lower in July and August, respectively, than in our $\mathrm{C}$ plots). The differing responses of the two species to the treatments and warming in particular can be attributed to their different inherent sensitivity to heat, in line with our third hypothesis [80-82].

Moreover, increased water availability under $W^{*} \mathrm{P}$ treatment did not compensate for heat stress in either species. Because summer temperatures in Korea are rapidly increasing, and the associated heat waves are expected to last longer in the future [56], the long-term survival of both $A$. holophylla and $A$. koreana may be compromised, requiring adaptation in silvicultural management in tree nurseries or the selection of alternative species in plantation forestry under future climatic conditions. Although the acclimation of photosynthesis was observed in the species in the post-stress period, further studies are needed to test whether or not such an acclimation would still occur under the extended period of heat waves. As the first open-field study on A. holophylla and A. koreana to combine warming and increased precipitation, the findings of this study would be useful for planning and managing both current and future afforestation efforts.

\section{Conclusions}

The physiology and growth responses of $A$. holophylla and A. koreana seedlings to open-field warming and increased precipitation treatments were investigated. Increasing the ambient air temperature by $3{ }^{\circ} \mathrm{C}$ had substantial negative impacts on the photosynthetic activity of both species, particularly A. koreana, with the stress severity exacerbated by summer heat waves. The warming effect on the shoot growth of seedlings was negligible during the first growing season. The supply of supplemental water amounting to $40 \%$ of the rainfall did not mitigate the heat or water stress induced by elevated temperatures. Post-stress recovery of photosynthesis activities was observed in A. holophylla under a cooler ambient temperature at the end of the growing season, whereas $A$. koreana exhibited $>90 \%$ mortality. Thus, A. holophylla is a more robust option for future planting, but adaptations to climate change might require alternative species and adjustment in the management of the species nurseries.

Supplementary Materials: The following are available online at https:/ /www.mdpi.com/article/10 .3390/w14030356/s1. Figure S1: (a) Satellite image of Korea, (b) Digital Elevation Model (DEM) of the study site, (c) aerial photo of the open-field experimental site, and (d) photos of the seedlings. Additional details on the experimental layout are provided in Figure S2. Figure S2: (a) Layout of the experimental plots and (b) design of the experimental warming and increased precipitation system. Table S1: Results ( $p$-values) of the initial ANOVA testing for the main and interaction effects of the experimental factors on the physiological (A, E, gs, Chl, Ci/Ca, and A/Ci) and growth parameters (height and RCD) of Abies holophylla and Abies koreana seedlings per month of assessment. Table S2: Effects of treatments on environmental factors. Figure S3: Monthly average $(a, d)$ air temperature, $(\mathrm{b}, \mathrm{e})$ soil temperature, and (c,f) soil volumetric water content for Abies holophylla and Abies koreana seedlings under the four treatments from July to September 2018. Error bars represent standard error of the mean. The treatments included control $(\mathrm{C})$, warming $(\mathrm{W})$, increased precipitation $(\mathrm{P})$, and both warming and increased precipitation $\left(\mathrm{W}^{*} \mathrm{P}\right)$. Trends in the variation of daily environmental data over the entire experimental period are presented in Figure 1. Figure S4: Effects of treatments on the relationships between net photosynthetic rate $\left(\mathrm{A}, \mu \mathrm{mol} \mathrm{m} \mathrm{m}^{-2} \mathrm{~s}^{-1}\right)$ and intracellular $\mathrm{CO} 2$ concentration $\left(\mathrm{Ci}, \mu \mathrm{mol} \mathrm{mol}{ }^{-1}\right)$ for $(\mathrm{a}-\mathrm{d})$ Abies holophylla and $(\mathrm{e}-\mathrm{h})$ Abies koreana from July to October. The treatments included control $(\mathrm{C})$, warming $(\mathrm{W})$, increased precipitation $(\mathrm{P})$, and both warming and increased precipitation $\left(\mathrm{W}^{*} \mathrm{P}\right)$.

Author Contributions: Conceptualization, H.J., H.C. and Y.S.; methodology, H.J. and H.C.; formal analysis, H.J. and F.N.; investigation, H.J.; resources, Y.S.; data curation, H.J.; writing-original draft preparation, H.J.; writing—review and editing, H.J., F.N., A.K., H.C. and Y.S.; visualization, H.J. and F.N.; supervision, F.N., A.K. and Y.S.; project administration, H.J., H.C. and Y.S.; funding acquisition, Y.S. All authors have read and agreed to the published version of the manuscript. 
Funding: This research was funded by the Korea Forest Service, grant numbers 2017058A00-1819AB01 and 2020181A00-2122-BB01.

Institutional Review Board Statement: Not applicable.

Informed Consent Statement: Not applicable.

Acknowledgments: This research was carried out with the support of National Research Foundation of Korea, grant numbers 4120200313708 and 2019R1I1A1A01064336. We thank the anonymous reviewers for the constructive comments on the earlier version of this paper.

Conflicts of Interest: The authors declare no conflict of interest. The funders had no role in the design of the study; in the collection, analyses, or interpretation of data; in the writing of the manuscript, or in the decision to publish the results.

\section{References}

1. IPCC. Climate Change 2014: Synthesis Report; Intergovernmental Panel on Climate Change: Geneva, Switzerland, 2014.

2. NIMS. Korea 100 Years Climate Change Report; National Institute of Meteorological Sciences: Seogwipo, Korea, 2018.

3. Hughes, L. Biological consequences of global warming: Is the signal already apparent? Trends Ecol. Evol. 2000, 15, 56-61. [CrossRef]

4. Spittlehouse, D.L.; Stewart, R.B. Adaptation to climate change in forest management. BC J. Ecosyst. Manag. 2003, 4, 1-11.

5. Ciais, P.; Reichstein, M.; Viovy, N.; Granier, A.; Ogée, J.; Allard, V.; Aubinet, M.; Buchmann, N.; Bernhofer, C.; Carrara, A.; et al. Europe-wide reduction in primary productivity caused by the heat and drought in 2003. Nature 2005, 437, 529-533. [CrossRef] [PubMed]

6. Schwalm, C.R.; Williams, C.A.; Schaefer, K.; Baldocchi, D.; Black, T.A.; Goldstein, A.H.; Law, B.E.; Oechel, W.C.; Paw, U.K.T.; Scott, R.L. Reduction in carbon uptake during turn of the century drought in western North America. Nat. Geosci. 2012, 5, 551-556. [CrossRef]

7. Williams, A.P.; Allen, C.D.; Macalady, A.K.; Griffin, D.; Woodhouse, C.A.; Meko, D.M.; Swetnam, T.W.; Rauscher, S.A.; Seager, R.; Grissino-Mayer, H.D.; et al. Temperature as a potent driver of regional forest drought stress and tree mortality. Nat. Clim. Change 2013, 3, 292-297. [CrossRef]

8. Mitchell, P.J.; O'Grady, A.P.; Hayes, K.R.; Pinkard, E.A. Exposure of trees to drought-induced die-off is defined by a common climatic threshold across different vegetation types. Ecol. Evol. 2014, 4, 1088-1101. [CrossRef]

9. FAO. Global Forest Resources Assessment; Food and Agriculture Organization of the United Nations: Rome, Italy, 2015.

10. Thompson, I.; Mackey, B.; McNulty, S.; Mosseler, A. Forest resilience, biodiversity, and climate change. In Secretariat of the Convention on Biological Diversity, Montreal; Technical Series No. 43. 1-67; Secretariat of the Convention on Biological Diversity: Montreal, QC, Canada, 2009; pp. 1-67.

11. Noulèkoun, F.; Khamzina, A.; Naab, J.B.; Khasanah, N.M.; Van Noordwijk, M.; Lamers, J.P.A. Climate Change Sensitivity of Multi-Species Afforestation in Semi-Arid Benin. Sustainability 2018, 10, 1931. [CrossRef]

12. Easterling, D.R.; Meehl, G.A.; Parmesan, C.; Changnon, S.A.; Karl, T.R.; Mearns, L.O. Climate extremes: Observations, modeling, and impacts. Science 2000, 289, 2068-2074. [CrossRef]

13. Reichstein, M.; Bahn, M.; Ciais, P.; Frank, D.; Mahecha, M.D.; Seneviratne, S.I.; Zscheischler, J.; Beer, C.; Buchmann, N.; Frank, D.C.; et al. Climate extremes and the carbon cycle. Nature 2013, 500, 287-295. [CrossRef]

14. Ruehr, N.K.; Gast, A.; Weber, C.; Daub, B.; Arneth, A. Water availability as dominant control of heat stress responses in two contrasting tree species. Tree Physiol. 2015, 36, 164-178. [CrossRef]

15. Ruehr, N.K.; Law, B.E.; Quandt, D.; Williams, M. Effects of heat and drought on carbon and water dynamics in a regenerating semi-arid pine forest: A combined experimental and modeling approach. Biogeosciences 2014, 11, 4139-4156. [CrossRef]

16. Haworth, M.; Marino, G.; Cosentino, S.L.; Brunetti, C.; De Carlo, A.; Avola, G.; Riggi, E.; Loreto, F.; Centritto, M. Increased free abscisic acid during drought enhances stomatal sensitivity and modifies stomatal behaviour in fast growing giant reed (Arundo donax L.). Environ. Exp. Bot. 2018, 147, 116-124. [CrossRef]

17. Chaves, M.M.; Maroco, J.P.; Pereira, J.S. Understanding plant responses to drought—from genes to the whole plant. Funct. Plant Biol. 2003, 30, 239-264. [CrossRef] [PubMed]

18. Ameye, M.; Wertin, T.M.; Bauweraerts, I.; McGuire, M.A.; Teskey, R.O.; Steppe, K. The effect of induced heat waves on Pinus taeda and Quercus rubra seedlings in ambient and elevated $\mathrm{CO}_{2}$ atmospheres. New Phytol. 2012, 196, 448-461. [CrossRef] [PubMed]

19. Berry, J.; Bjorkman, O. Photosynthetic response and adaptation to temperature in higher plants. Annu. Rev. Plant Physiol. 1980, 31, 491-543. [CrossRef]

20. Hikosaka, K.; Ishikawa, K.; Borjigidai, A.; Muller, O.; Onoda, Y. Temperature acclimation of photosynthesis: Mechanisms involved in the changes in temperature dependence of photosynthetic rate. J. Exp. Bot. 2006, 57, 291-302. [CrossRef]

21. Yamori, W.; Hikosaka, K.; Way, D.A. Temperature response of photosynthesis in C3, C4, and CAM plants: Temperature acclimation and temperature adaptation. Photosynth. Res. 2014, 119, 101-117. [CrossRef]

22. McWilliam, J.R.; Naylor, A.W. Temperature and plant adaptation. I. Interaction of temperature and light in the synthesis of chlorophyll in corn. Plant Physiol. 1967, 42, 1711-1715. [CrossRef] 
23. Ormrod, D.P.; Lesser, V.M.; Olszyk, D.M.; Tingey, D.T. Elevated Temperature and Carbon Dioxide Affect Chlorophylls and Carotenoids in Douglas-Fir Seedlings. Int. J. Plant Sci. 1999, 160, 529-534. [CrossRef]

24. Tewari, A.K.; Tripathy, B.C. Temperature-Stress-Induced Impairment of Chlorophyll Biosynthetic Reactions in Cucumber and Wheat. Plant Physiol. 1998, 117, 851-858. [CrossRef]

25. Muller, B.; Pantin, F.; Génard, M.; Turc, O.; Freixes, S.; Piques, M.; Gibon, Y. Water deficits uncouple growth from photosynthesis, increase $C$ content, and modify the relationships between $C$ and growth in sink organs. J. Exp. Bot. 2011, 62, 1715-1729. [CrossRef] [PubMed]

26. Vu, J.C.V.; Allen, L.H., Jr.; Boote, K.J.; Bowes, G. Effects of elevated $\mathrm{CO}_{2}$ and temperature on photosynthesis and Rubisco in rice and soybean. Plant Cell Environ. 1997, 20, 68-76. [CrossRef]

27. Tjoelker, M.G.; Oleksyn, J.; Reich, P.B. Seedlings of five boreal tree species differ in acclimation of net photosynthesis to elevated $\mathrm{CO}_{2}$ and temperature. Tree Physiol. 1998, 18, 715-726. [CrossRef] [PubMed]

28. Driscoll, W.W.; Wiles, G.C.; D'Arrigo, R.D.; Wilmking, M. Divergent tree growth response to recent climatic warming, Lake Clark National Park and Preserve, Alaska. Geophys. Res. Lett. 2005, 32, 1-4. [CrossRef]

29. Han, S.; Lee, S.J.; Yoon, T.K.; Han, S.H.; Lee, J.; Kim, S.; Hwang, J.; Cho, M.S.; Son, Y. Species-specific growth and photosynthetic responses of first-year seedlingsof four coniferous species to open-field experimental warming. Turk. J. Agric. For. 2015, 39, 342-349. [CrossRef]

30. Jo, H.; Chang, H.; An, J.; Cho, M.S.; Son, Y. Species specific physiological responses of Pinus densiflora and Larix kaempferi seedlings to open-field experimental warming and precipitation manipulation. For. Sci. Technol. 2019, 15, 44-50. [CrossRef]

31. Cao, J.; Liu, H.; Zhao, B.; Li, Z.; Drew, D.M.; Zhao, X. Species-specific and elevation-differentiated responses of tree growth to rapid warming in a mixed forest lead to a continuous growth enhancement in semi-humid Northeast Asia. For. Ecol. Manag. 2019, 448, 76-84. [CrossRef]

32. Jassey, V.E.J.; Signarbieux, C. Effects of climate warming on Sphagnum photosynthesis in peatlands depend on peat moisture and species-specific anatomical traits. Glob. Chang. Biol. 2019, 25, 3859-3870. [CrossRef]

33. Haworth, M.; Marino, G.; Brunetti, C.; Killi, D.; De Carlo, A.; Centritto, M. The impact of heat stress and water deficit on the photosynthetic and stomatal physiology of olive (Olea europaea L.) -A case study of the 2017 heat wave. Plants 2018, 7, 76. [CrossRef]

34. Smith, B.G.; Stephens, W.; Burgess, P.J.; Carr, M.K.V. Effects of light, temperature, irrigation and fertilizer on photosynthetic rate in tea (Camellia sinensis). Exp. Agric. 1993, 29, 291-306. [CrossRef]

35. Shrive, S.C.; McBride, R.A.; Gordon, A.M. Photosynthetic and Growth Responses of Two Broad-Leaf Tree Species to Irrigation with Municipal Landfill Leachate. J. Environ. Qual. 1994, 23, 534-542. [CrossRef]

36. Khamzina, A.; Sommer, R.; Lamers, J.P.A.; Vlek, P.L.G. Transpiration and early growth of tree plantations established on degraded cropland over shallow saline groundwater table in northwest Uzbekistan. Agric. For. Meteorol. 2009, 149, 1865-1874. [CrossRef]

37. Vu, J.C.V.; Yelenosky, G. Photosynthetic responses of citrus trees to soil flooding. Physiol. Plant. 1991, 81, 7-14. [CrossRef]

38. Fernández, M. Changes in photosynthesis and fluorescence in response to flooding in emerged and submerged leaves of Pouteria orinocoensis. Photosynthetica 2006, 44, 32-38. [CrossRef]

39. Khamzina, A.; Lamers, J.P.A.; Vlek, P.L.G. Tree establishment under deficit irrigation on degraded agricultural land in the lower Amu Darya River region, Aral Sea Basin. For. Ecol. Manag. 2008, 255, 168-178. [CrossRef]

40. Cha, Y.-G.; Choi, K.-S.; Song, K.-S.; Sung, H.-I.; Kim, J.-J. Growth characteristics of one-year-old container seedlings of Pinus densiflora by irrigation level. Prot. Hortic. Plant Fact. 2017, 26, 167-174. [CrossRef]

41. Noulèkoun, F.; Lamers, J.P.; Naab, J.; Khamzina, A. Shoot and root responses of woody species to silvicultural management for afforestation of degraded croplands in the Sudano-Sahelian zone of Benin. For. Ecol. Manag. 2017, 385, 254-263. [CrossRef]

42. Noulèkoun, F.; Khamzina, A.; Naab, J.B.; Lamers, J.P. Biomass allocation in five semi-arid afforestation species is driven mainly by ontogeny rather than resource availability. Ann. For. Sci. 2017, 74, 1-12. [CrossRef]

43. Xiang, X.; Cao, M.; Zhou, Z. Fossil history and modern distribution of the genus Abies (Pinaceae). Front. For. China 2007, 2, 355-365. [CrossRef]

44. Seong, E.S.; Kim, S.K.; Lee, J.W.; Choi, S.H.; Yoo, J.H.; Lim, J.D.; Na, J.K.; Yu, C.Y. Antioxidant and antibacterial activities of the byproducts of Abies holophylla extract. Korean J. Med. Crop Sci. 2018, 26, 134-140. [CrossRef]

45. Kim, J.; Lee, D.K.; Kim, H.G. Suitable trees for urban landscapes in the Republic of Korea under climate change. Landsc. Urban Plan. 2020, 204, 103937. [CrossRef]

46. Koo, K.-A.; Park, W.-K.; Kong, W.-S. Dendrochronological analysis of Abies koreana W. at Mt. Halla, Korea: Effects of climate change on the growths. Korean J. Ecol. 2001, 24, 281-288.

47. Woo, S.Y. Forest decline of the world: A linkage with air pollution and global warming. Afr. J. Biotechnol. 2009, 8, 7409-7414.

48. Koo, K.A.; Kong, W.-S.; Park, S.U.; Lee, J.H.; Kim, J.; Jung, H. Sensitivity of Korean fir (Abies koreana Wils.), a threatened climate relict species, to increasing temperature at an island subalpine area. Ecol. Model. 2017, 353, 5-16. [CrossRef]

49. Kim, Y.S.; Chang, C.S.; Kim, C.S.; Gardner, M. Abies Koreana. The IUCN Red List of Threatened Species 2011. 2011. Available online: https:/ /dx.doi.org/10.2305/IUCN.UK.2011-2.RLTS.T31244A9618913.en (accessed on 3 November 2021).

50. Kimball, B.A.; Conley, M.M.; Wang, S.; Lin, X.; Luo, C.; Morgan, J.; Smith, D. Infrared heater arrays for warming ecosystem field plots. Glob. Chang. Biol. 2008, 14, 309-320. [CrossRef] 
51. Mensah, S.; Noulekoun, F.; Dimobe, K.; Atanasso, J.; Salako, V.K.; Assogbadjo, A.; Kakaï, R.G. Revisiting biotic and abiotic drivers of seedling establishment, natural enemies and survival in a tropical tree species in a West Africa semi-arid biosphere reserve. J. Environ. Manag. 2020, 276, 111268. [CrossRef]

52. Haase, D.L. Understanding forest seedling quality: Measurements and interpretation. Tree Plant. Notes 2008, 52, $24-30$.

53. Shevtsova, A.; Graae, B.J.; Jochum, T.; Milbau, A.; Kockelbergh, F.; Beyens, L.; Nijs, I. Critical periods for impact of climate warming on early seedling establishment in subarctic tundra. Glob. Chang. Biol. 2009, 15, 2662-2680. [CrossRef]

54. Korea Meteorological Administration. Automatic Weather Station (AWS) Observations; Korea Meteorological Administration: Seoul, Korea, 2020.

55. Korea Forest Service. Guidelines for Seed and Seedling Management; Korea Forest Service: Daejeon, Korea, 2015.

56. Korea Global Atmosphere Watch Center (KGAWC). RCP Korean Peninsula Scenario; KGAWC: Seoul, Korea, 2005.

57. Harte, J.; Shaw, R. Shifting Dominance Within a Montane Vegetation Community: Results of a Climate-Warming Experiment. Science 1995, 267, 876-880. [CrossRef]

58. Kimball, B.A. Theory and performance of an infrared heater for ecosystem warming. Glob. Chang. Biol. 2005, 11, 2041-2056. [CrossRef]

59. Hiscox, J.; Israelstam, G. A method for the extraction of chlorophyll from leaf tissue without maceration. Can. J. Bot. 1979, 57, 1332-1334. [CrossRef]

60. Went, F.W. The effect of temperature on plant growth. Annu. Rev. Plant Physiol. 1953, 4, 347-362. [CrossRef]

61. Daniell, J.W.; Chappell, W.; Couch, H. Effect of sublethal and lethal temperature on plant cells. Plant Physiol. 1969, 44, 1684-1689. [CrossRef] [PubMed]

62. Harding, S.A.; Guikema, J.A.; Paulsen, G.M. Photosynthetic decline from high temperature stress during maturation of wheat: II. Interaction with source and sink processes. Plant Physiol. 1990, 92, 654-658. [CrossRef]

63. Salvucci, M.E.; Crafts-Brandner, S.J. Inhibition of photosynthesis by heat stress: The activation state of Rubisco as a limiting factor in photosynthesis. Physiol. Plant. 2004, 120, 179-186. [CrossRef]

64. Allakhverdiev, S.I.; Kreslavski, V.D.; Klimov, V.V.; Los, D.A.; Carpentier, R.; Mohanty, P. Heat stress: An overview of molecular responses in photosynthesis. Photosynth. Res. 2008, 98, 541-550. [CrossRef]

65. Woo, S.Y.; Lim, J.-H.; Lee, D.K. Effects of Temperature on Photosynthetic Rates in Korean Fir (Abies koreana) between Healthy and Dieback Population. J. Integr. Plant Biol. 2008, 50, 190-193. [CrossRef]

66. Sánchez-Salguero, R.; Ortíz, C.; Covelo, F.; Ochoa, V.; García-Ruíz, R.; Seco, J.I.; Carreira, J.A.; Merino, J.Á.; Linares, J.C. Regulation of Water Use in the Southernmost European Fir (Abies pinsapo Boiss.): Drought Avoidance Matters. Forests 2015, 6, 2241-2260. [CrossRef]

67. Fang, O.; Qiu, H.; Zhang, Q.-B. Species-specific drought resilience in juniper and fir forests in the central Himalayas. Ecol. Indic. 2020, 117, 106615. [CrossRef]

68. Dusenge, M.E.; Duarte, A.G.; Way, D.A. Plant carbon metabolism and climate change: Elevated $\mathrm{CO}_{2}$ and temperature impacts on photosynthesis, photorespiration and respiration. New Phytol. 2019, 221, 32-49. [CrossRef]

69. Crawford, A.J.; McLachlan, D.H.; Hetherington, A.M.; Franklin, K.A. High temperature exposure increases plant cooling capacity. Curr. Biol. 2012, 22, R396-R397. [CrossRef] [PubMed]

70. Je, S.M.; Kim, S.H.; Woo, S.Y. Responses of the photosynthetic apparatus of Abies koreana to drought under different light conditions. Ecol. Res. 2018, 33, 413-423. [CrossRef]

71. Larcher, W.; Wagner, J.; Lütz, C. The effect of heat on photosynthesis, dark respiration and cellular ultrastructure of the arctic-alpine psychrophyte Ranunculus glacialis. Photosynthetica 1998, 34, 219-232. [CrossRef]

72. Robakowski, P.; Montpied, P.; Dreyer, E. Temperature response of photosynthesis of silver fir (Abies alba Mill.) seedlings. Ann. For. Sci. 2002, 59, 163-170. [CrossRef]

73. Gallé, A.; Feller, U. Changes of photosynthetic traits in beech saplings (Fagus sylvatica) under severe drought stress and during recovery. Physiol. Plant. 2007, 131, 412-421. [CrossRef]

74. Miyashita, K.; Tanakamaru, S.; Maitani, T.; Kimura, K. Recovery responses of photosynthesis, transpiration, and stomatal conductance in kidney bean following drought stress. Environ. Exp. Bot. 2005, 53, 205-214. [CrossRef]

75. Kim, E.-S.; Cho, H.-B.; Heo, D.; Kim, N.-S.; Kim, Y.-S.; Lee, K.; Lee, S.-H.; Ryu, J. Precision monitoring of radial growth of trees and micro-climate at a Korean Fir (Abies koreana Wilson) forest at 10 minutes interval in 2016 on Mt. Hallasan National Park, Jeju Island, Korea. J. Ecol. Environ. 2019, 43, 226-245. [CrossRef]

76. Gazol, A.; Camarero, J.J.; Gutiérrez, E.; Popa, I.; Andreu-Hayles, L.; Motta, R.; Nola, P.; Ribas, M.; Sangüesa-Barreda, G.; Urbinati, C. Distinct effects of climate warming on populations of silver fir (Abies alba) across Europe. J. Biogeogr. 2015, 42, 1150-1162. [CrossRef]

77. Smith, A.M.; Stitt, M. Coordination of carbon supply and plant growth. Plant Cell Environ. 2007, 30, 1126-1149. [CrossRef]

78. Chapin, F.S., III; Shaver, G.R. Physiological and growth responses of arctic plants to a field experiment simulating climatic change. Ecology 1996, 77, 822-840. [CrossRef]

79. Hanley, M.E.; Fenner, M.; Whibley, H.; Darvill, B. Early plant growth: Identifying the end point of the seedling phase. New Phytol. 2004, 163, 61-66. [CrossRef] [PubMed]

80. Kotak, S.; Larkindale, J.; Lee, U.; von Koskull-Döring, P.; Vierling, E.; Scharf, K.-D. Complexity of the heat stress response in plants. Curr. Opin. Plant Biol. 2007, 10, 310-316. [CrossRef] [PubMed] 
81. Friedrichs, D.A.; Trouet, V.; Büntgen, U.; Frank, D.C.; Esper, J.; Neuwirth, B.; Löffler, J. Species-specific climate sensitivity of tree growth in Central-West Germany. Trees 2009, 23, 729-739. [CrossRef]

82. Cunningham, S.; Read, J. Comparison of temperate and tropical rainforest tree species: Photosynthetic responses to growth temperature. Oecologia 2002, 133, 112-119. [CrossRef] 